\title{
Free Insulin Measurement
}

National Cancer Institute

\section{Source}

National Cancer Institute. Free Insulin Measurement. NCI Thesaurus. Code C147377.

The determination of the amount of free insulin present in a sample. 